\title{
Humanized Monoclonal Antibody Blocking Carbonic Anhydrase 12 Enzymatic Activity Leads to Reduced Tumor Growth In Vitro
}

\author{
NARASIMHA RAO UDA ${ }^{1,2}$, FRANK STENNER ${ }^{1,3}$, VOLKER SEIBERT $^{4,5}$, PETRA HERZIG $^{1}$, \\ NORBERT MARKULY ${ }^{1,6}$, MARC VAN DIJK ${ }^{4,7}$, ALFRED ZIPPELIUS ${ }^{1,3}$ and CHRISTOPH RENNER ${ }^{1}$ \\ ${ }^{1}$ Cancer Immunology Laboratory, Department of Biomedicine, University \\ Hospital Basel, University of Basel, Basel, Switzerland; \\ ${ }^{2}$ School of Pharmaceutical Sciences, Faculty of Sciences, University of Geneva, Geneva, Switzerland; \\ ${ }^{3}$ Division of Oncology, Department of Internal Medicine, University Hospital Basel, Basel, Switzerland; \\ ${ }^{4}$ Agenus Inc. USA (4-Antibody AG), Basel, Switzerland; \\ ${ }^{5}$ Lonza AG, Visp, Switzerland; \\ ${ }^{6} \mathrm{Cureab} \mathrm{GmbH}$, Riehen, Switzerland; \\ ${ }^{7}$ AgenTus Therapeutics, Cambridge, U.K.
}

\begin{abstract}
Background/Aim: Carbonic anhydrase 12 (CA12) is a membrane-associated enzyme that is highly expressed on many human cancers. It is a poor prognostic marker and hence an attractive target for cancer therapy. This study aimed to develop a humanized CA12-antibody with anticancer activity. Materials and Methods: Antibody libraries were constructed and screened by the Retrocyte display ${ }^{\circledR}$. Antibody binding and blocking properties were determined by ELISA, flow cytometry and enzymatic activity assays. Spheroid viability was determined by Cell-Titer-Fluor assay. Results: We developed a novel humanized CA12-specific antibody, 4AG4, which recognized CA12 as an antigen and blocked CA12 enzymatic activity. Our humanized CA12antibody significantly inhibited spheroid growth of lung adenocarcinoma A549-cells in vitro by blocking CA12 enzymatic activity. Similar anti-tumor effects were recapitulated with CA12-gene knockout of A549-cells. Conclusion: Our newly identified humanized CA12-antibody with anti-cancer activity, represents a new tool for the treatment of CA12-positive tumors.
\end{abstract}

Carbonic anhydrases are enzymes that are involved in cellular $\mathrm{pH}$ homeostasis by catalyzing the reversible inter-

Correspondence to: Christoph Renner and Narasimha Rao Uda, Hebelstrasse 20, Laboratory Cancer Immunology, Department of Biomedicine, University of Basel, 4001 Basel, Switzerland. Tel: +410612652355, e-mail: christoph.renner@unibas.ch; e-mail: narasimha.uda@unige.ch

Key Words: Carbonic anhydrase 12, cancer, hypoxia, therapeutic antibodies. conversion of a carbon dioxide and a water molecule into dissociated-ions of carbonic acid (bicarbonate \& hydrogen ions). There are 15 different $\mathrm{CA}$ isoforms known in mammalian cells differing in their sub-cellular localization and activity, of which four CAs (CA4, CA9, CA12 \& CA14) are membrane-associated and expressed on the cell surface. CA9 and CA12 were shown to have cancer-specific expression in several human cancers and further to be overexpressed in hypoxic tumors favoring cancer progression, metastasis and poor patient survival (1-3). Hypoxic cancer cells are known to switch their cellular metabolism from oxidative phosphorylation to anaerobic glycolysis producing lactic acid that increases extracellular $\mathrm{pH}(\mathrm{pHe})$ in the tumor micro-environment (4-6).

Hypoxia-induced exofacial CA9 and CA12 expression has been shown to play a key role in developing resistance to tumor hypoxia and extracellular acidosis (4, 5). Mechanistically, CA9 and CA12 produce and transport bicarbonate ions into the cells through anion exchangers and $\mathrm{Na}^{+} / \mathrm{HCO}_{3}{ }^{-}$co-transporters (7) leading to favorable intracellular $\mathrm{pH}(\mathrm{pHi})$ for cancer cell growth and proliferation and on the other hand causing unfavorable extracellular acidosis to the non-cancerous stromal cells in the tumor micro-environment (8). Dysregulation of $\mathrm{pHi}$ either by small-molecule inhibitors or by knockdown of CA9 or CA12 has been shown to reduce tumor growth and migration $(8,9)$ and hence inhibiting CA9 or CA12 enzymatic activity has been considered as an attractive anticancer therapeutic strategy (10).

An important role of carbonic anhydrases in cancer was suggested more than two decades ago (11) and the two known cancer-associated carbonic anhydrases so far, CA9 (12) and CA12 (13), were characterized in 1990's. However, 
most of the progress in understanding their role in tumorigenesis and the anti-tumor mechanisms behind their inhibition has been achieved only in recent years $(8,14)$. Functional implication of CA9 in tumor physiology (15) and its therapeutic potential have been extensively studied by its targeting with both small molecule-inhibitors and antibodies $(16,17)$. At least two small molecule-inhibitors targeting CA9 have entered phase I clinical trials $(18,19)$ and one antibody is in phase III clinical trial for the treatment of clear cell renal cell carcinoma (20). Numerous antibody formats such as, antibody-dependent cellular cytotoxicity (ADCC) antibodies (21), antibody-drug conjugates (ADCs) (22) and radio-labeled antibodies $(23,24)$ have been studied for their therapeutic efficacy by targeting CA9 (25). On the other hand, the anti-cancer therapeutic approach of targeting CA12 has been relatively less explored $(26,27)$.

Blocking the enzymatic activity of CA12 by antibodies compared to small-molecule inhibitors is a very novel and safe approach due to the high specificity of antibodies. However, it is extremely challenging to identify antibodies that can block enzymatic activity just by specifically binding on the surface of the CA12 protein without having any direct interactions with the CA12 catalytic pocket. So far, there is only one well-characterized antibody reported for blocking CA12 enzymatic activity $(26,28)$, but it is a fully rat antibody, making it difficult to translate this antibody into a human setting. Hence, in the current study, we aimed to generate humanized monoclonal antibodies with anti-cancer activity by blocking the CA12 enzymatic activity.

\section{Materials and Methods}

Heavy- and light-chain recovery. Genomic DNA was isolated from FACS-single cell sorted cell population (Macherey-Nagel GmbH \& Co. KG, Düren, Germany). VH and $V_{K}$ genes were amplified by PCR, sequenced and cloned into expression vectors. The resulting ligated plasmids were transfected into $\mathrm{CHO}$ cells for antibody expression and purification.

Retrocyte Display ${ }^{\circledR}$ cellular antibody libraries. Retrocyte displayed cellular antibody libraries were constructed as previously described (29). Briefly, heavy- and light-chain gene libraries were packaged separately into replication-incompetent retroviral particles in HEK 293 cells expressing gag-pol and env genes (pVPack vector system, Stratagene, La Jolla, CA, USA) using FuGENE6 Transfection Reagent (Roche Diagnostics Deutschland GmbH, Mannheim, Germany) according to manufacturer's instructions. The resulting retroviral supernatants were harvested after three days and kept frozen at $-80^{\circ} \mathrm{C}$. $1624-5$ pre-B cells were spin-transduced with retroviral supernatants for $3 \mathrm{~h}$ at $30^{\circ} \mathrm{C}$ as previously described (30). Heavy- and light-chain gene libraries were transduced separately and sequentially. Transduction was done in 6-well plates (Cellstar, Greiner Bio-One Vacuette Switzerland GmbH, St. Gallen, Switzerland) with $1.5 \times 10^{8}$ cells per plate and in Eppendorf centrifuges. Following transduction, cells were transferred in Erlenmeyer flasks $\left(3 \times 10^{6}\right.$ cells $\left./ \mathrm{ml}\right)$ and allowed to expand for $24 \mathrm{~h}$.
Flow cytometry. CA12 binding antibodies were identified by flowcytometric analysis of the Retrocyte Display ${ }^{\circledR}$ cellular antibody libraries using the following antibodies; Fc-block 1:200, IgLambdaPE 1:80, CA12-biotin 1:1000 \& SAV-APC 1:1000.

Fluorescence-activated cell sorting (FACS) was performed using BD FACS Aria I or II with FACS Diva software (Becton-Dickinson Switzerland Sàrl, Eysins, Switzerland). Each round of FACS enrichment was performed using labeled CA12 for $30 \mathrm{~min}$ at $4^{\circ} \mathrm{C}$. Streptavidin (SAV) coupled to PE or APC was added for $15 \mathrm{~min}$ at $4^{\circ} \mathrm{C}$ for detection of biotinylated antigen. Bound non-specific cells were gated out during FACS. In addition, anti-human IgL antibody was used to visualize antibody expression levels. All washes between labelling reactions were done by centrifuging cells for 10 min at $300 \mathrm{rpm}$ at $4^{\circ} \mathrm{C}$ in PBS with $2 \%$ FCS. Single cell clones were analyzed in 96-well plates on a BD FACS Calibur. All flow cytometry data were analyzed using FlowJo software (Treestar Inc., Ashland, OR, USA).

ELISA. Immuno ${ }^{\mathrm{TM}}$ Nunc 96-well plate was coated with $100 \mu \mathrm{l}$ of 2 $\mu \mathrm{g} / \mathrm{ml}$ CA 9 or CA12 in PBS buffer per well. The plate was sealed and incubated overnight at $4^{\circ} \mathrm{C}$. After incubation, the plate was washed twice with PBS buffer and blocked with $1 \%$ Bovine gelatin in PBS for $1 \mathrm{~h}$ at RT (room temperature). Gelatin was washed twice with PBS and then incubated with primary antibody at a concentration of $5 \mu \mathrm{g} / \mathrm{ml}$ for about $1.5 \mathrm{~h}$ at $37^{\circ} \mathrm{C}$. Unbound primary antibody was removed by washing thrice with PBS. Secondary-HRP (Horse Radish Peroxidase) conjugated antibody (anti-human $1: 20,000$ and anti-rat 1:10,000) was incubated for about $1 \mathrm{~h}$ at RT and washed thrice with PBS. HRP substrate, freshly prepared TMBsolution pre-warmed to RT was added and incubated for $30 \mathrm{~min}$ at $\mathrm{RT}$ in the dark place. The HRP reaction (color formation) is stopped by adding $2 \mathrm{~N} \mathrm{H}_{2} \mathrm{SO}_{4}$, which turns the TMB substrate into a stable yellow color and then absorbance is read at $450 \mathrm{~nm}$ in a 96 -well plate reader, Synergy ${ }^{\mathrm{TM}}$ H1 multi-mode microplate reader from BioTek, Luzern, Switzerland.

Antibody production. CA9 antibodies MSC8 (25) \& MSC12 (25) and CA12 antibody 6A10 (28) with specific binding and blocking activity, published by us and other groups, were re-cloned and produced at 4-Antibody AG (Agenus Inc., Lexington, MA, USA) and designated as $4 \mathrm{AG} 1,4 \mathrm{AG} 2$ and $4 \mathrm{AG} 3$, respectively. In brief, transient transfection of both heavy and light chain expression vectors into FS-CHO cells was performed for the production of IgG. Transfected cells were grown in FreeStyle CHO-S/BD-Select CHO medium. Antibodies were purified by chromatography on proteinA columns.

Esterase activity assay (31). The reaction to assay for the esterase activity included the following components: $5 \mu \mathrm{g} / \mathrm{ml}$ of CA12 (114 $\mathrm{nM}), 1 \mathrm{mM}$ of substrate, $p$ NPA, in $100 \mu \mathrm{l}$ of assay buffer $(12.5 \mathrm{mM}$ Tris, $75 \mathrm{mM} \mathrm{NaCl}$ and $\mathrm{pH} 7.5$ ). The final concentration of CA12 was determined by titrating the enzyme at a fixed concentration $(1 \mathrm{mM})$ of 4-nitrophenyl acetate (4-NPA $/ p N P A)$ substrate. For inhibition studies, CA12 enzyme was pre-incubated with antibodies at $37^{\circ} \mathrm{C}$ for $1 \mathrm{~h}$. In all cases, the reaction was initiated by adding the substrate, and the enzyme activity was measured by monitoring the production of colored product, 4-nitrophenol (4-NP/pNP), at $400 \mathrm{~nm}$ every $3 \mathrm{~min}$ for about $2 \mathrm{~h}$ at $37^{\circ} \mathrm{C}$. In all cases, the background absorbance of spontaneous hydrolysis of the substrate alone or in the presence of negative/isotype control antibodies was subtracted from the absorbance of CA12 
mediated hydrolysis. Slope of the initial velocity of enzymatic activity was calculated by plotting absorbance $(400 \mathrm{~nm})$ on Y-axis and time (min) on $\mathrm{X}$-axis. The slope of the initial rate of reaction was converted to the percentage of enzyme activity. Percentage of inhibition of antibodies was calculated by considering the enzyme activity in the absence of antibodies as $100 \%$. The $\mathrm{IC}_{50}$ values were obtained by the non-linear least-squares method using PRISM 6 (Graphpad Prism Software Inc., La Jolla, CA, USA).

Cell lines and culture conditions. A549 lung adenocarcinoma cells were cultured $\left(1-5 \times 10^{5}\right.$ cells $)$ in $75 \mathrm{~mm}^{2}$ flasks $(15 \mathrm{ml}$ DMEM/flask) for 3 days under normoxic $\left(5 \% \mathrm{CO}_{2}\right)$ and hypoxic $\left(1 \% \mathrm{O}_{2}\right.$ and $\left.5 \% \mathrm{CO}_{2}\right)$ conditions at $37^{\circ} \mathrm{C}$. Bicarbonate free DMEM medium (D2902, Sigma-Aldrich, St Louis, MO, USA) supplemented with glucose to $4 \mathrm{~g} / \mathrm{l}$, buffered with $20 \mathrm{mM}$ HEPES, adjusted to $\mathrm{pH} 7.4$ with $\mathrm{NaOH}$ and filter sterilized.

CA12-gene knock-out in A549-cells. The human CA12-specific CRISPR Cas9 gene knock-out plasmid and corresponding control plasmid with 20 nucleotide non-specific guide RNA (gRNA) were purchased from Santa Cruz Biotechnology, Inc., Heidelberg, Germany. Human CA12-specific CRISPR Cas9 plasmid consisting of a pool of 3 plasmids, each having a wildtype Cas 9 nuclease, human CA12-specific $20 \mathrm{nt}$ gRNA for maximal knockout efficiency and the sequence encoding green fluorescence protein. At 70-80\% confluency, A549 cells were transfected in a 6-well plate, separately, with CA12-specific CRISPR Cas9 plasmids and with control plasmids of non-specific gRNA (mock-transfection) using $2 \mu \mathrm{g}$ of plasmid and $10 \mu \mathrm{l}$ of lipofectamine 2000 reagent (Invitrogen, Carlsbad, CA, USA). After overnight incubation, cells were detached by trypsinization and sorted for transfection positive cells with green fluorescence. Transfection positive cells were expanded and three CA12-negative cells were sorted per well in a 96-well plate. Four of the sorted CA12-negative poly clones were further expanded and CA12-knockout was confirmed at the genetic level by DNA sequencing and at protein level by flow cytometry of cells cultured under normoxic and hypoxic conditions. The mocktransfected (plasmid with non-specific gRNA) A549 cells were treated in the same way as the CA12-negative cells and used as a mock/control for the functional assays.

Expression of CA9 and CA12 in cancer cell lines by FACS analysis. Adherent cells were detached by Trypsin EDTA, re-suspended in FACS buffer (2\% FSC in PBS), incubated with primary antibody specific for CA9 and CA12 for $30 \mathrm{~min}$ on ice and washed twice with FACS buffer. Fluorochrome conjugated secondary antibodies specific for the primary antibodies were added for $30 \mathrm{~min}$ on ice and cells were washed twice with FACS buffer and stained with Sytox green for differentiating live dead cells. The expression levels of CA9 and CA12 were determined by gating on the live cells compared with proper isotype controls. FACS was performed by BD Accuri C6 and the data were analyzed by using FlowJo software (Treestar Inc., Ashland, OR, USA).

Cell-Tire Fluor protease assay for spheroid viability. We have established an in vitro functional assay "Cell-Titer-Fluor assay" to quantify cell viability of cells cultured in the form of spheroids in a hanging drop. The "Cell-Titer-Fluor assay" measures the protease activity of living cells (Promega AG, Dübendorf, Switzerland). Adherent cells were detached by $0.05 \%$ Trypsin-EDTA solution (Life technologies, Carlsbad, CA, USA) and cell clumps were removed by $100 \mu \mathrm{m}$ cell strainer. Cells were re-suspended in a bicarbonate free DMEM medium (20 mM HEPES \& $\mathrm{pH} 7.2$ ) containing $0.2 \%$ methylcellulose and $8 \%$ FCS. 10,000 cells in $40 \mu \mathrm{l}$ of medium with and without $50 \mu \mathrm{g} / \mathrm{ml}$ antibodies were placed in 8-replicates in a 96well plate designed for spheroid formation in a hanging drop (Insphero AG, Zurich, Switzerland). After 4-days of incubation in hypoxic $\left(1 \% \mathrm{O}_{2} \& 5 \% \mathrm{CO}_{2}\right)$ or normoxic $\left(21 \% \mathrm{O}_{2} \& 5 \% \mathrm{CO}_{2}\right)$ incubators, spheroids in the hanging drops were collected in clearbottom 96-well black-walled plates (3340, Corning Inc., Corning, NY, USA) containing $30 \mu \mathrm{l}$ of cell-titer-fluor mix per well. The plate was briefly centrifuged $(2 \mathrm{~min}$ at $1,500 \mathrm{rpm})$ and incubated at $37^{\circ} \mathrm{C}$ for $3 \mathrm{~h}$ in hypoxic or normoxic incubators. The fluorescent signal in the spheroids measured every $30 \mathrm{~min}$ at $380 \mathrm{~nm}$ excitation and 505 $\mathrm{nm}$ emission is directly proportional to the protease activity of the living cells in the spheroid. After the incubation, images of spheroids were taken under a light microscope.

\section{Results}

Strategy for generating fully-human and humanized CA12 antibodies. The only known CA12-blocking antibody to date is the rat 6A10 antibody $(28,31)$, which was successfully recloned and produced as $4 \mathrm{AG} 3$. In our efforts to obtain the first fully-human CA12 antibody that can specifically bind to CA12 and block its enzymatic activity, guided-selection was first used to screen for CA12 binding antibodies. In the second approach, a humanized version of 4AG3 was generated by CDR grafting on a human antibody backbone.

Guided selection for fully human novel CA12 antibodies. We used the Retrocyte display ${ }^{\circledR}$ technology (29) for the construction of three human antibody libraries (Sy11, Sy7,8,9 and CB3), each with a theoretical diversity of 1$5 \times 10^{8}$ antibodies using random human heavy and light chain combinations as described earlier (29). In the first round of guided selection strategy, the complex library of human heavy chains was randomly aligned with the light chain of our reference CA12 antibody, 4AG3, and the complex library of human light chains was randomly aligned with the heavy chain of our reference CA12 antibody, 4AG3, respectively. The newly identified human heavy and light chains of CA12 binding antibodies of the first round of guided selection were then combined to generate completely new CA12 specific fully human antibodies. Unexpectedly and to our surprise, flow-cytometric screening (Figure 1A) did not reveal any CA12 binding antibodies from the first round of guided selection, neither with the complex human heavy chain nor with the human light chain libraries combined with the counterpart of the reference rat antibody $4 \mathrm{AG} 3$.

Humanization of rat CA12 antibody, 4AG3. We then decided to humanize the existing CA12 rat-antibody, 4AG3, in a two-step process. First, the CDR's of rat antibody were grafted onto a human antibody backbone and in the second 


\section{A}

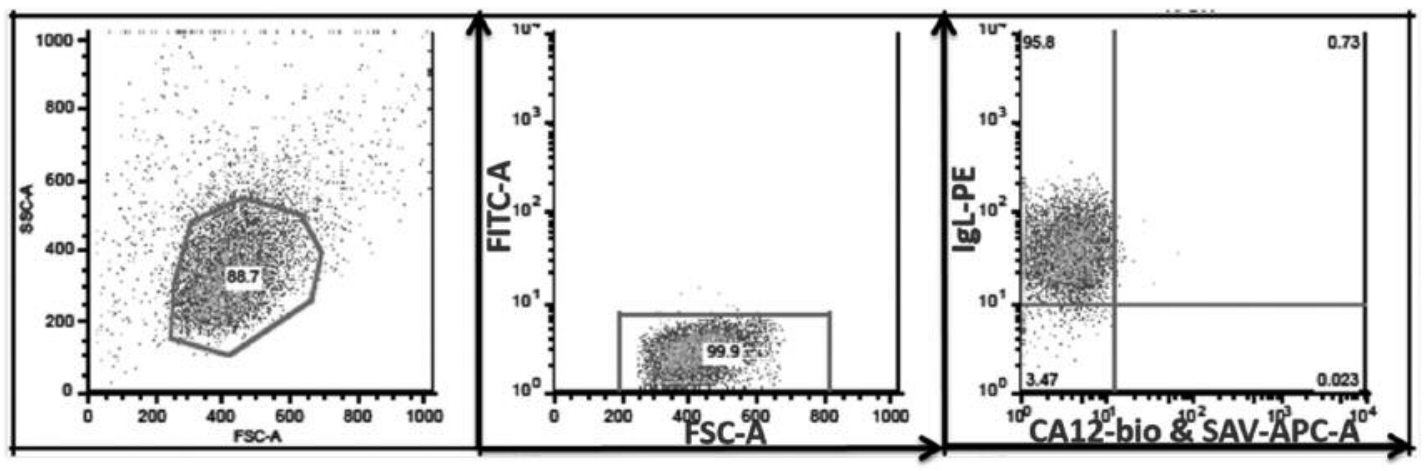

B

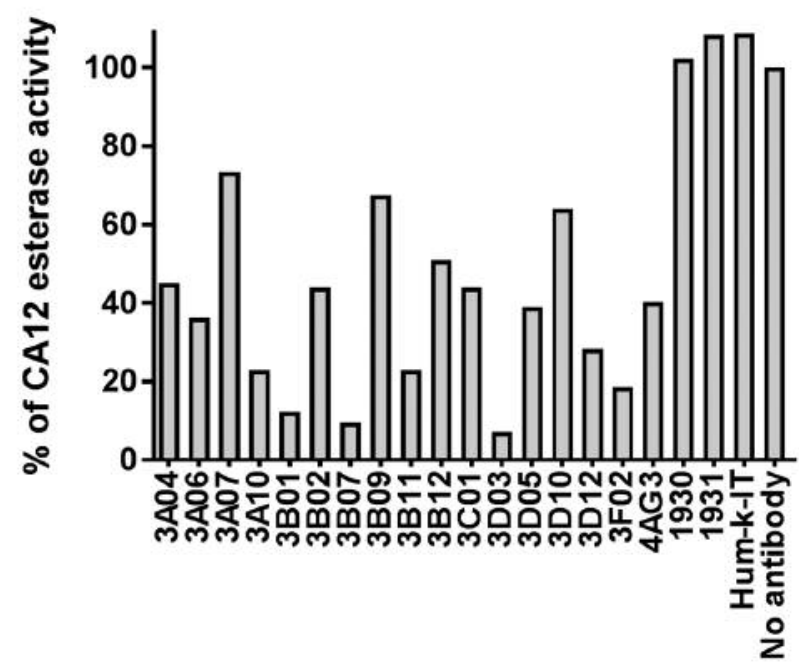

Figure 1. Screening of antibodies for CA12 binding and blocking CA12 esterase activity. (A) Identification of CA12-binding human antibodies from guided selection. Flow-cytometric analysis of Retrocyte Display ${ }^{\circledR}$ cellular antibody libraries. Gating strategy of library 1624-5, clone 1984 HD $3 B V L+V h$, left FACS plot shows typical forward and side scattering of cells, middle FACS-plot was gated on live cells and right FACS-plot has cells displaying antibody with I lambda light chain stained with PE (Phycoerythrin) on the y-axis and on the x-axis cells displaying CA12 binding antibody stained with APC (Allophycocyanin). (B) Identification of humanized antibodies blocking esterase activity. Antibodies 1930, 1931 \& Hum$k-I T(20 \mu \mathrm{g} / \mathrm{ml})$ are negative controls for CA12 inhibition and antibody $4 A G 3(20 \mu \mathrm{g} / \mathrm{ml})$ is the positive control for CA12 inhibition. The final concentration of all other antibodies tested, varied between $0.3 \mu \mathrm{g} / \mathrm{ml}$ and $20 \mu \mathrm{g} / \mathrm{ml}$. Enzymatic activity after $1.5 \mathrm{~h}$ at $37^{\circ} \mathrm{C}$, was normalized to $100 \%$ using the condition in the absence of any antibody. The measurements are representative of two independent experiments.

step, the light chain was completely replaced with a novel human light chain by de novo screening of a human light chain library.

In the first step of humanization, in addition to grafting of rat CDR heavy and light chain regions on human heavy and light chain backbones, simultaneous random mutations were introduced generating novel antibody sequences. Consequently, 16 humanized antibodies were identified, that could bind to human CA12, and inhibit CA12 enzymatic activity with various degrees of efficacy (Figure 1B) as determined by using CA12 esterase enzymatic activity as a surrogate assay for CA12 hydratase activity (31). In a dose- depended titration of all 16 humanized antibodies against CA12 enzymatic activity four antibodies demonstrated $\mathrm{IC}_{50}$ concentrations similar to that of the $\mathrm{IC}_{50}$ of the original rat antibody, 4AG3 (Figure 2 and Table I).

In the second step, we further evolved the humanized CA12 antibodies by using Retrocyte Display ${ }^{\circledR}$. The newly identified humanized heavy chain from the first step of humanization was used in a guided selection screen as described above, to identify novel light chains by combining the humanized heavy chain with a complex primary "naïve" light chain library with a theoretical diversity of $10^{8}$ light chains. Finally, a novel CA12 antibody was identified that 
Table I. Comparison of $I C_{50}$ values of humanized antibodies.

\begin{tabular}{ll}
\hline Humanized CA12 blocking antibodies & $\mathrm{IC}_{50}(\mu \mathrm{g} / \mathrm{ml})$ \\
\hline 4AG3 (rat antibody) & $27 \mu \mathrm{g} / \mathrm{ml} \pm 7$ \\
3B01 (humanized) & $14 \mu \mathrm{g} / \mathrm{ml} \pm 4$ \\
3B07 (humanized) & $17 \mu \mathrm{g} / \mathrm{ml} \pm 4$ \\
3D03 (humanized) & $21 \mu \mathrm{g} / \mathrm{ml} \pm 6$ \\
3F02 (humanized) & $25 \mu \mathrm{g} / \mathrm{ml} \pm 7$ \\
\hline
\end{tabular}

Table II. Comparison of $I C_{50}$ values of humanized antibodies with novel human light chain.

\begin{tabular}{lc}
\hline $\begin{array}{l}\text { CA12 blocking humanized antibodies } \\
\text { with novel human light chain }\end{array}$ & $\mathrm{IC}_{50}(\mu \mathrm{g} / \mathrm{ml})$ \\
\hline 4AG3 (rat antibody) & $27 \mu \mathrm{g} / \mathrm{ml} \pm 7$ \\
4AG4 (humanized antibody) & $08 \mu \mathrm{g} / \mathrm{ml} \pm 2$ \\
4AG6 (humanized antibody) & $10 \mu \mathrm{g} / \mathrm{ml} \pm 4$ \\
4AG8 (humanized antibody) & $13 \mu \mathrm{g} / \mathrm{ml} \pm 4$ \\
4AG11 (humanized antibody) & $13 \mu \mathrm{g} / \mathrm{ml} \pm 4$ \\
4AG12 (humanized antibody) & $09 \mu \mathrm{g} / \mathrm{ml} \pm 2$ \\
4AG13 (humanized antibody) & $16 \mu \mathrm{g} / \mathrm{ml} \pm 7$ \\
\hline
\end{tabular}

combined a fully human light chain and a humanized heavy chain. This antibody showed specific binding to CA12 and blocking against CA12 enzymatic activity. Six humanized CA12 antibodies with a novel light chain showed relatively better $\mathrm{IC}_{50}$ values than 4AG3, (Figure 3 and Table II).

One of the above six novel antibodies, 4AG4, was selected and produced at large-scale ( $>100 \mathrm{mg}$ ) for further functional characterization in vitro. We validated the antibody 4AG4 for its stability at $4^{\circ} \mathrm{C}$ for one week and two freeze-thaw cycles using its CA12 binding and blocking efficiency in two different buffers (Figure 4). 4AG4 antibody in comparison with 4AG3 has the same efficiency of CA12 binding (Figure 4A and B) and CA12 blocking (Figure 4C and D) in these two different buffers (PBS and Tris). Storage at $4^{\circ} \mathrm{C}$ for a week and two freeze-thaw cycles of 4AG4 antibody had no significant effect on its CA12 binding and blocking capability (Figure 4).

Antibody specificity. The newly identified 4AG4 antibody was tested for cross reactivity with CA9 in comparison with the existing CA9 binding (4AG2), blocking (4AG1) and CA12-blocking (4AG3) antibodies previously published by us and other groups $(25,28,31)$. 4AG4 antibody demonstrated no cross reactivity to CA9, neither in binding (Figure 5A) nor in blocking the CA9 enzymatic activity (Figure 5B). 4AG1 antibody is a CA9 blocking antibody and hence displayed specific binding and blocking of CA9, whereas 4AG2 is only a CA9 binding antibody and did not block enzymatic activity (Figure 5). The newly developed humanized antibody, 4AG4, showed a specific binding and blocking of CA12 in a manner very similar to the existing rat antibody of CA12, 4AG3 (Figure 5).

Humanized antibody, 4AG4, reduced spheroid growth. The A549 lung adenocarcinoma cell line was used to quantify the functional efficacy of our CA12 blocking antibodies. A549-cells were cultured in the form of spheroids in hanging drops with and without antibodies. The newly humanized CA12 antibody 4AG4 significantly reduced spheroid viability, both in normoxic (Figure 6A) and hypoxic (Figure 6B) conditions similar to the rat 4AG3CA12 antibody. The reduced viability of A549-cells treated with 4AG4 was evident by the reduced size of the spheroid under hypoxic conditions (Figure 7). Cells treated with other control antibodies such as CA9 binding (4AG2) and CA9 blocking (4AG1) antibodies did not show any inhibitory effect on the viability (Figure 6) and also on spheroid formation (Figure 7). Spheroid growth was affected only by the CA12 blocking antibody 4AG4, but not with the CA9 blocking antibody, 4AG1, which is in agreement with the physiological expression pattern of CA9 and CA12 in A549-cells. A549-cells have no CA9 expression under normoxic conditions and a very slight inducible-expression under hypoxic conditions, which is in contrast to the very high CA12 expression under normoxia with further over-expression under hypoxia (Table III).

Humanized CA12-antibody is as efficient as CA12-gene knockout. Further, a CA12-gene knockout variant of A549cells was constructed using CRISPR-Cas9 technology to confirm that the reduced spheroid growth by 4AG4 antibody is through blocking the cellular CA12-enzymatic activity. Survival of CA12-gene knockout A549-cells cultured in the absence of antibody was similar to the reduced cell survival of wildtype-A549-cells and mock-A549-cells treated with 4AG4 antibody (Figure 8). In addition, upon 4AG4 antibody treatment, CA12-gene knockout A549-cells did not show any further reduction in the cell survival. The results remained the same both under normoxic and hypoxic conditions, suggesting that CA12 enzymatic inhibition in wildtype or CA12 genetic knockout may not be compensated by slight over-expression of CA9 in hypoxic condition.

\section{Discussion}

Hypoxia has been one of the major obstacles in the treatment of solid cancers and specific targeting of hypoxia responsive genes is still a major area of research in the development of new cancer treatments. Hypoxia-induced CA12 expression has been shown to promote metastasis in various cancers $(32,33)$ through regulation of intracellular $\mathrm{pH}(8)$. High levels of CA12 have been associated with several cancers, thyroid cancer (34), squamous lung cancer (27) gastric 

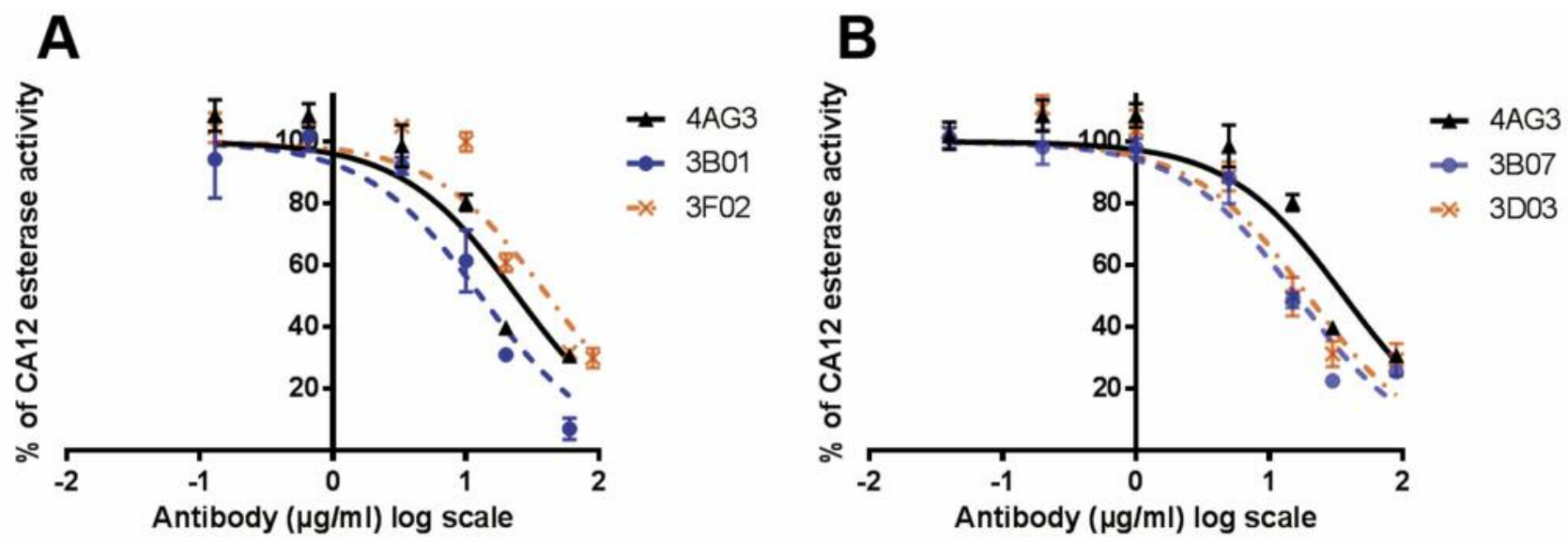

Figure 2. Dose dependent inhibition of CA12 enzymatic activity by humanized antibodies. The measurements are representative of two independent experiments performed in triplicates. 4AG3 is our reference antibody for the inhibition of CA12 enzymatic activity. Enzymatic activity was normalized to $100 \%$ using the condition without any antibody. $I C_{50}$ values of the antibodies (Table I) were calculated using Graphpad Prism Software.
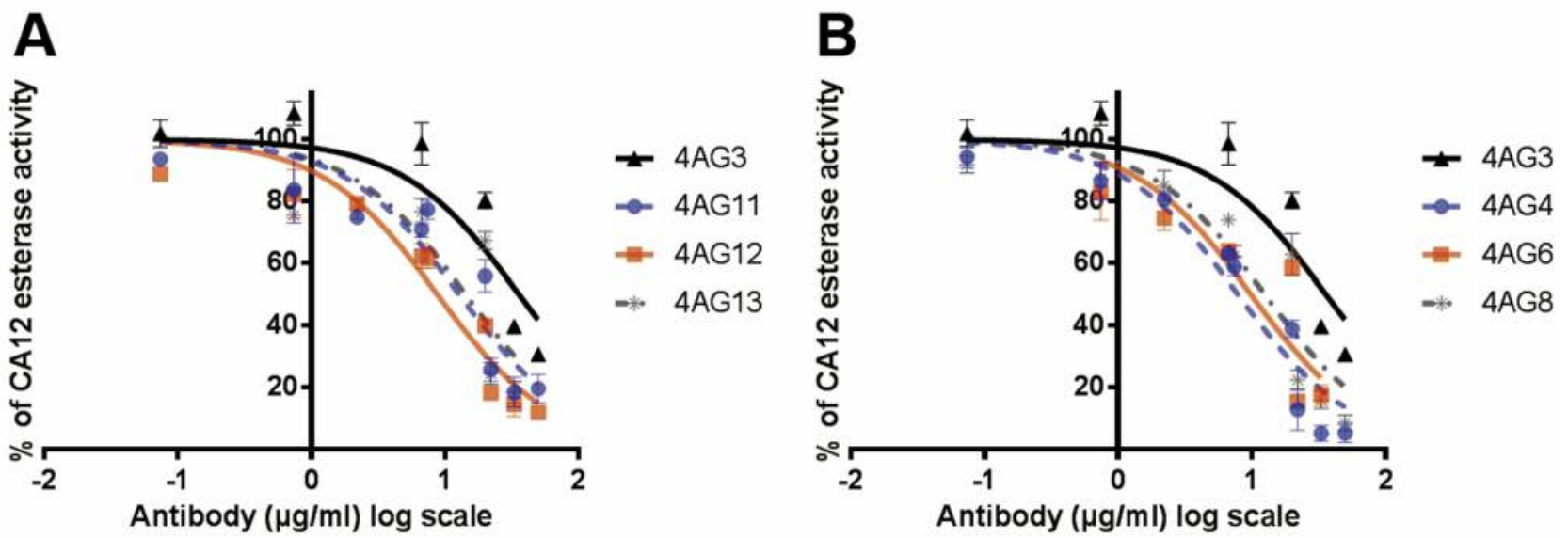

Figure 3. Dose-dependent inhibition of CA12 enzymatic activity by humanized antibodies with novel light chain. The measurements are representative of two independent experiments performed in triplicates. 4AG3 is our reference antibody for the inhibition of CA12 enzymatic activity. Enzymatic activity was normalized to $100 \%$ using the condition without any antibody. IC ${ }_{50}$ values of the antibodies (Table II) were calculated using Graphpad Prism Software.

tumors (35), colorectal cancers (36) and breast cancer (37). Several CA12 expressing cancers including gliomas (38), oral (39) and esophageal (40) squamous cell cancer show poor prognosis.

Despite extensive preclinical research, so far only two molecules have entered clinical trials targeting CA9 (18), but none targeting CA12. This is likely due to the potential offtarget effects of inhibiting 10 other active CA isoforms. Therefore, the use of CA9 and CA12 blocking monoclonal antibodies is a novel anti-cancer therapeutic approach to avoid off-target effects of blocking other CA isoforms and to discriminate healthy cells from cancer cells expressing CA9 \& CA12 $(26,27,41,42)$. The above studies indicate the importance of therapeutic potential of antibody-mediated CA12 targeted therapies, particularly in CA12 expressing cancers.

In the current study, our efforts to generate fully human antibody against CA12 through guided selection were unsuccessful, despite using three complex libraries of human heavy and light chains to randomize with the counterparts of our reference rat CA12 antibody, 4AG3. The recombinant CA12 protein used for screening for CA12-binding antibodies was biotinylated and contained 17 additional $\mathrm{N}$ terminal amino acids (including 6His-tag), which to some extent might have hindered binding of newly randomized antibodies generated through guided selection. It is also 

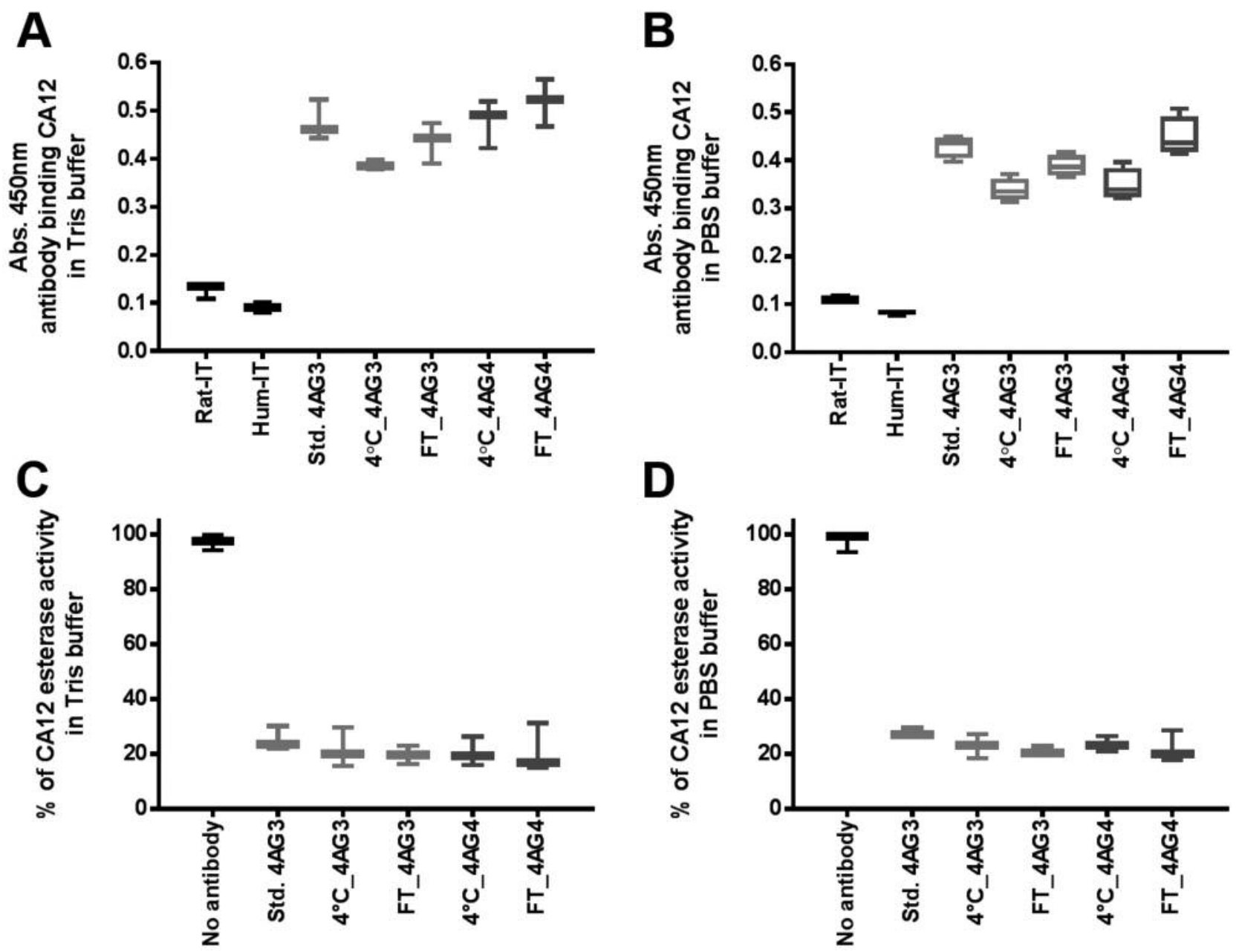

Figure 4. Stability of 4AG4. Antibodies showing their CA12 binding ability in Tris (A) and PBS (B) buffers in ELISA and CA12 blocking ability in Tris $(C)$ and PBS $(D)$ buffers in esterase enzymatic assay. The measurements shown here are averages and standard deviation of quadruplicates. $4 A G 3$ is our reference antibody for the inhibition of CA12 enzymatic activity. All antibodies were tested at $40 \mu \mathrm{g} / \mathrm{ml}$ concentration for the inhibition of enzymatic reaction. Enzymatic activity after $1.5 \mathrm{~h}$ at $37^{\circ} \mathrm{C}$ was normalized to $100 \%$ using the condition without any antibody. Std.: Standard antibody stored at $-80^{\circ} \mathrm{C}$ for long term storage, $4^{\circ} \mathrm{C}$ storage for a week and FT: two Freeze Thawing cycles.

possible that the specific binding to CA12 may require a very specific sequence and confirmation of antibody CDRs, which might be less frequent in nature.

In a second attempt, a humanized CA12-antibody was successfully generated by grafting the CDR's of rat antibody on a human antibody backbone followed by replacement of humanized light chain with a completely new human light chain. The newly humanized CA12 antibody, 4AG4, showed specific binding to human CA12 and also inhibited CA12 enzymatic activity. In addition, 4AG4 antibody significantly reduced spheroid growth of human lung-adenocarcinoma cells, A549, confirming its anti-tumor properties.

Similar reduction in spheroid growth in both normoxic and hypoxic conditions suggested that 4AG4 antibody is
Table III. Expression of cancer-associated carbonic anhydrases (CA9 \& CA12) in A549 cell line.

\begin{tabular}{lcccc}
\hline Cell line & $\begin{array}{c}\text { CA9 in } \\
21 \% \mathrm{O}_{2}\end{array}$ & $\begin{array}{c}\text { CA9 in } \\
1 \% \mathrm{O}_{2}\end{array}$ & $\begin{array}{c}\text { CA12 in } \\
21 \% \mathrm{O}_{2}\end{array}$ & $\begin{array}{c}\text { CA12 } \\
\text { in } \mathrm{O}_{2}\end{array}$ \\
\hline
\end{tabular}

A549

$\begin{array}{lllll}\text { Lung carcinoma } & -/+ & ++ & +++++ & ++++++\end{array}$

GMFI values; $0-1 \mathrm{~K}$ is no expression $(-), 1 \mathrm{~K}-2 \mathrm{~K}$ is very low expression $(-/+), 2 \mathrm{~K}-10 \mathrm{~K}$ is low expression $(+), 10 \mathrm{~K}-25 \mathrm{~K}$ is moderate expression $(++), 25 \mathrm{~K}-50 \mathrm{~K}$ is high expression $(+++), 50 \mathrm{~K}-150 \mathrm{~K}$ is very high expression (++++) and $>150 \mathrm{~K}$ is extremely high expression (+++++). Only single stainings were performed in each sample for each surfaceexpressed carbonic anhydrase in order to avoid any steric hindrance between the antibodies of different CA's. 

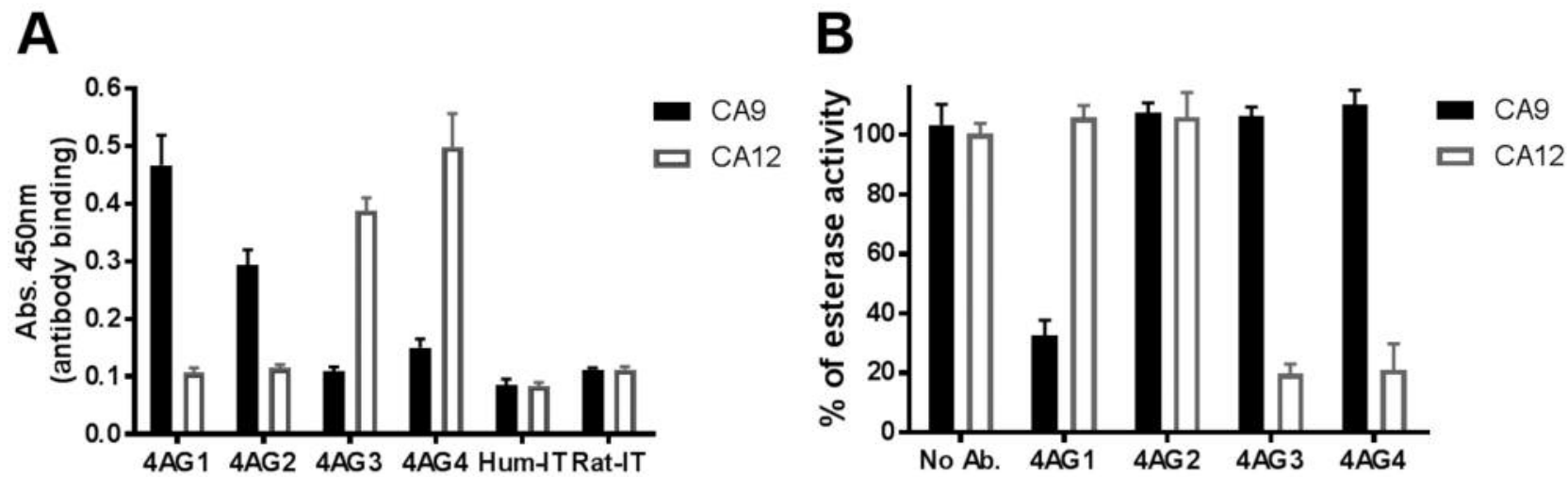

Figure 5. Specificity of 4AG4 antibody. Binding activity of antibodies was assayed by ELISA (A) and blocking ability by esterase enzymatic activity assay $(B)$. The data shown is a representative of two independent experiments performed in triplicates. All the antibodies were tested at $40 \mu \mathrm{g} / \mathrm{ml}$ concentration for the inhibition of enzymatic activity. Enzymatic activity after $1.5 \mathrm{~h}$ at $37^{\circ} \mathrm{C}$ was normalized to $100 \%$ using the condition without any antibody.

A

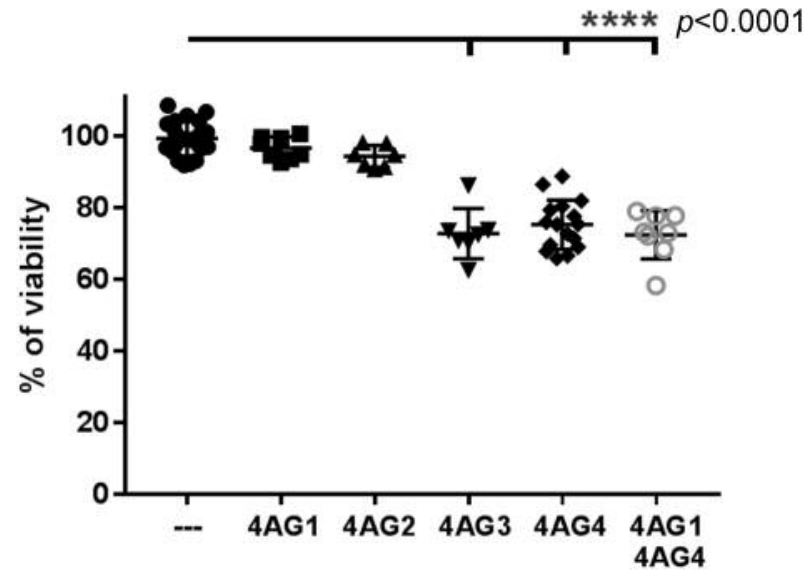

B

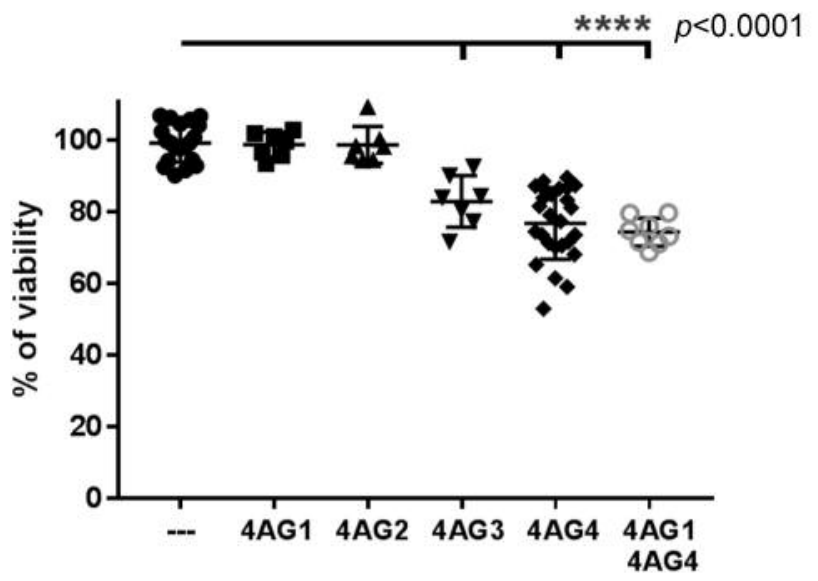

Figure 6. Quantification of living cells by Cell-Titer-Flour assay. Cells were cultured in bicarbonate free DMEM medium (cat. no. D5648, SigmaAldrich), buffered with $20 \mathrm{mM}$ Hepes and supplemented with $10 \%$ FCS. A549 cell spheroids incubated in InSphero hanging drop plates with different antibodies, each at $40 \mu \mathrm{g} / \mathrm{ml}$, for 3 days under normoxic (A) and hypoxic (B) conditions. Significance was calculated using Ordinary one-way ANOVA Multiple comparisons with Prism 6. The data shown here is an average of 2-3 independent experiments performed in 6 replicates.

efficient in blocking the CA12 enzymatic activity even under hypoxia-mediated over expression of CA12. In addition, CA12-gene knockout cells cultured in the presence or absence of 4AG4 antibody showed reduced viability similar to wildtype and mock-A549-cells treated with 4AG4 antibody. This confirmed that the reduced cell viability is likely due to 4AG4-mediated blocking of CA12-enzymatic activity and also suggested that our 4AG4 antibody is as efficient as complete CA12-gene knockout construct in blocking the CA12 enzymatic activity. Our data emphasizes that CA12 catalytic activity is critical for cancer cell physiology and thereby for tumor growth.
Our data of reduced spheroid growth by humanized CA12 antibody treatment and by CA12-gene knockout are in agreement with previous publications of CA12 targeting, where CA12 knockdown xenograft mouse model showed $85 \%$ reduction in tumor growth (8) and sensitized tumor cells for radiotherapy by increasing the intracellular acidosis (43). Another study has shown that pharmacological inhibition of CA12 could induce apoptosis in T-cell lymphomas (44). Several small-molecule inhibitors designed against CA9 have shown promising anti-cancer effects by blocking the CA12 enzymatic activity $(17,18)$. In spite of a having significant number of patent protected small-molecule inhibitors against 

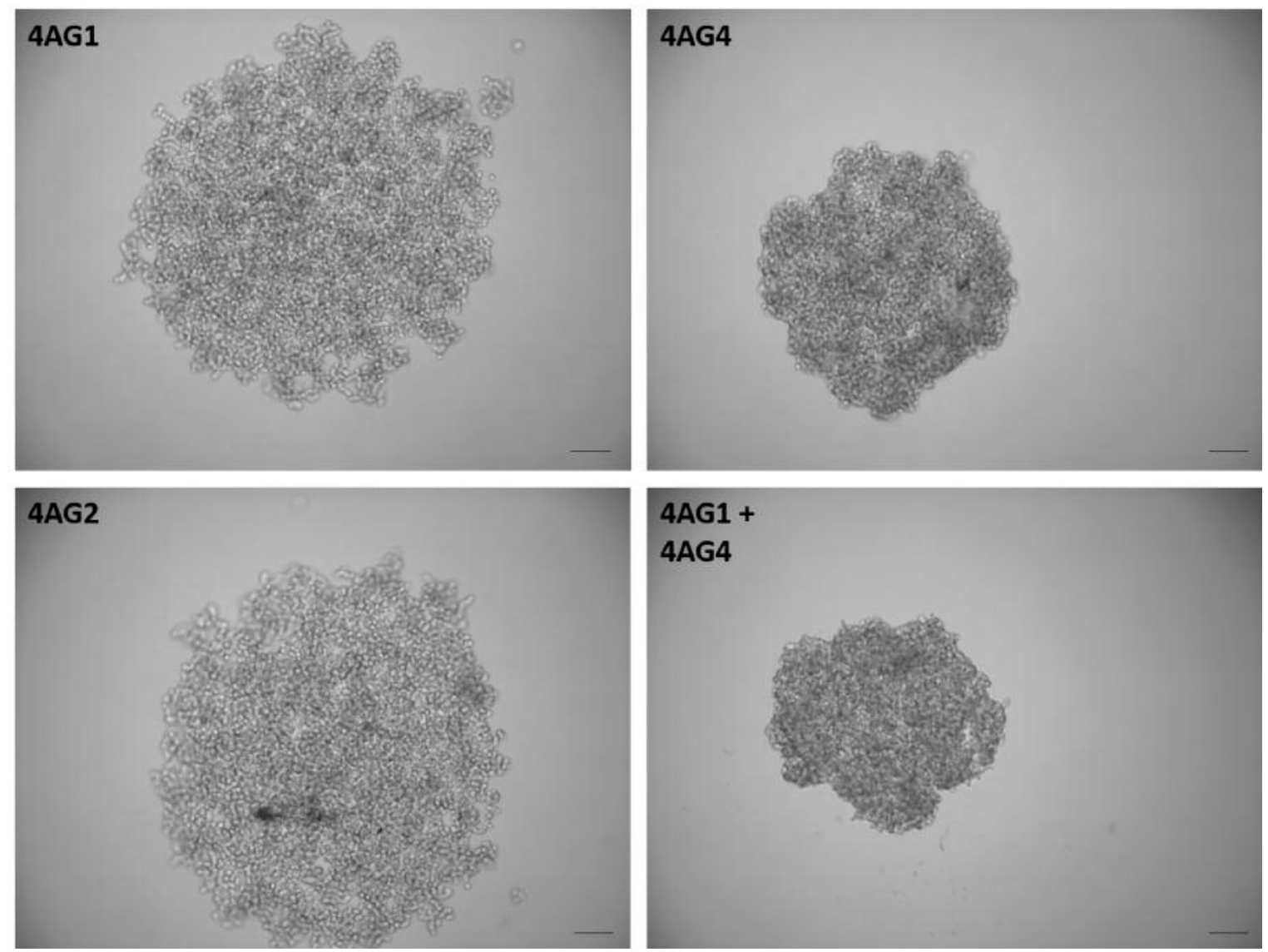

Figure 7. Size of A549 spheroids after 3 days of incubation with different antibodies under hypoxia. The concentration of each antibody was $40 \mu \mathrm{g} / \mathrm{ml}$. Spheroid images were taken using light microscope at 10x magnification.
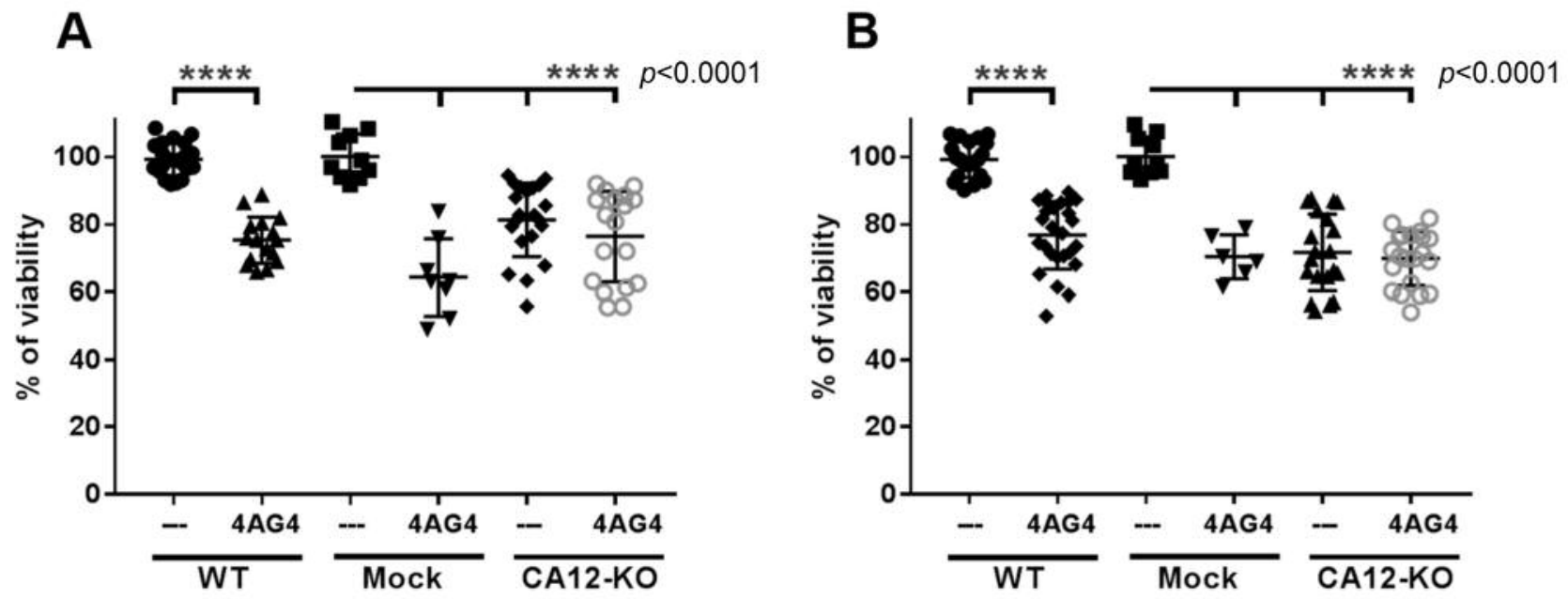

Figure 8. Spheroid growth of wild-type and CA12-knockout A549 cells. Cell viability of spheroids with or without $4 A G 4$ at $50 \mu \mathrm{g} / \mathrm{ml}$, was assayed after 4 days under normoxic (A) and hypoxic (B) conditions. Significance was calculated using Ordinary one-way ANOVA Multiple comparisons with Prism 6. 
carbonic anhydrase enzymatic activity, isoform specific antibodies are superior due to their CA12-specificity in blocking tumor CA12 enzymatic activity and also in delivering drug conjugates specifically to the tumor site.

It has recently been discovered that CA12 is also coexpressed with a known drug-resistant surface protein, Pglycoprotein, on cancer cells and blocking CA12 enzymatic activity re-sensitized drug resistant cancers $(26,45,46)$. Treatment of triple-negative breast cancer with CA12 antibody and doxorubicin significantly reduced metastatic events in a xenograft mouse model (26). These studies indicate that blocking CA12 enzymatic activity as a monotherapy or in combination with other chemotherapeutic agents could be a promising approach to treat drug resistant cancers. Our study on the newly developed humanized antibody against CA12 enzymatic activity will promote CA12 targeted anti-cancer therapeutic studies to the next level of preclinical and clinical studies which may establish antibody-mediated CA12 inhibition as a successful anticancer therapeutic approach.

\section{Conflicts of Interest}

The co-authors Dr. Volker Seibert and Dr. Marc van Dijk were employees of 4-Antibody AG, Basel, Switzerland (wholly-owned subsidiary of Agenus Inc., Lexington, MA, USA).

\section{Authors' Contributions}

C.R. and F.S. conceived the original idea. A.Z., C.R., F.S., M.V.D., N.R.U. and V.S. designed the study \& developed the theoretical framework. A.Z., C.R., F.S. and M.V.D. supervised the findings of this work. F.S., N.R.U. and V.S. designed the experiments. N.R.U. and V.S. carried out the experiments, processed and analyzed the experimental data. N.M. and P.H. helped with experiments and provided technical support. All authors contributed to the interpretation of the results. N.R.U. took the lead in writing the manuscript with the help of C.R. and V.S. All Authors contributed to the final manuscript with critical feedback.

\section{Acknowledgements}

The Authors are grateful to Michal Stanczak, Achim Klein and Alessandra Franchino for technical support. The Authors would like to thank the 4-Antibody (Agenus Inc.) team in Basel and in Jena for antibody production. The Authors thank Prof. Carole Bourquin for the encouragement and kind support to NRU and the CTI: Commission for Technology and Innovation (now, Innosuisse), Switzerland, for the financial support, project number 14446.1 PFLS-LS.

\section{References}

1 Wykoff CC, Beasley NJP, Watson PH, Turner KJ, Pastorek J, Sibtain A, Wilson GD, Turley H, Talks KL, Maxwell PH, Pugh CW, Ratcliffe PJ and Harris AL: Hypoxia-inducible expression of tumor-associated carbonic anhydrases. Cancer Res 60(24): 7075-7083, 2000. PMID: 11156414.
2 Ilie MI, Hofman V, Ortholan C, El Ammadi R, Bonnetaud C, Havet K, Venissac N, Mouroux J, Mazure NM, Pouyssegur J and Hofman P: Overexpression of carbonic anhydrase xii in tissues from resectable non-small cell lung cancers is a biomarker of good prognosis. Int J Cancer 128(7): 1614-1623, 2011. PMID: 20521252. DOI: $10.1002 / \mathrm{ijc} .25491$

3 Lomelino C and McKenna R: Carbonic anhydrase inhibitors: A review on the progress of patent literature (2011-2016). Expert Opin Ther Pat 26(8): 947-956, 2016. PMID: 27387065. DOI: $10.1080 / 13543776.2016 .1203904$

4 Swietach P, Patiar S, Supuran CT, Harris AL and Vaughan-Jones RD: The role of carbonic anhydrase 9 in regulating extracellular and intracellular ph in three-dimensional tumor cell growths. $\mathrm{J}$ Biol Chem 284(30): 20299-20310, 2009. PMID: 19458084. DOI: $10.1074 /$ jbc.M109.006478

5 Estrella V, Chen TA, Lloyd M, Wojtkowiak J, Cornnell HH, Ibrahim-Hashim A, Bailey K, Balagurunathan Y, Rothberg JM, Sloane BF, Johnson J, Gatenby RA and Gillies RJ: Acidity generated by the tumor microenvironment drives local invasion. Cancer Res 73(5): 1524-1535, 2013. PMID: 23288510. DOI: 10.1158/0008-5472.Can-12-2796

6 Vaupel P, Kallinowski F and Okunieff P: Blood-flow, oxygen and nutrient supply, and metabolic microenvironment of humantumors - a review. Cancer Res 49(23): 6449-6465, 1989. PMID: 2684393.

7 Morgan PE, Pastorekova S, Stuart-Tilley AK, Alper SL and Casey JR: Interactions of transmembrane carbonic anhydrase, caix, with bicarbonate transporters. Am J Physiol Cell Physiol 293(2): C738-C748, 2007. PMID: 17652430. DOI: 10.1152/ ajpcell.00157.2007

8 Chiche J, Ilc K, Laferriere J, Trottier E, Dayan F, Mazure NM, Brahimi-Horn MC and Pouyssegur J: Hypoxia-inducible carbonic anhydrase ix and xii promote tumor cell growth by counteracting acidosis through the regulation of the intracellular ph. Cancer Res 69(1): 358-368, 2009. PMID: 19118021. DOI: 10.1158/0008-5472.Can-08-2470

9 McIntyre A, Patiar S, Wigfield S, Li JL, Ledaki I, Turley H, Leek R, Snell C, Gatter K, Sly WS, Vaughan-Jones RD, Swietach P and Harris AL: Carbonic anhydrase ix promotes tumor growth and necrosis in vivo and inhibition enhances antivegf therapy. Clin Cancer Res 18(11): 3100-3111, 2012. PMID: 22498007. DOI: 10.1158/1078-0432.Ccr-11-1877

10 Nocentini A and Supuran CT: Carbonic anhydrase inhibitors as antitumor/antimetastatic agents: A patent review (2008-2018). Expert Opin Ther Pat 28(10): 729-740, 2018. PMID: 30074415. DOI: $10.1080 / 13543776.2018 .1508453$

11 Teicher BA, Liu SD, Liu JT, Holden SA and Herman TS: A carbonic-anhydrase inhibitor as a potential modulator of cancer therapies. Anticancer Res 13(5a): 1549-1556, 1993. PMID: 8239534.

12 Pastorek J, Pastorekova S, Callebaut I, Mornon JP, Zelnik V, Opavsky R, Zatovicova M, Liao S, Portetelle D, Stanbridge EJ, Zavada J, Burny A and Kettmann R: Cloning and characterization of $\mathrm{mn}$, a human tumor-associated protein with a domain homologous to carbonic-anhydrase and a putative helix-loop-helix DNAbinding segment. Oncogene 9(10): 2877-2888, 1994. PMID: 8084592.

13 Tureci O, Sahin U, Vollmar E, Siemer S, Gottert E, Seitz G, Parkkila AK, Shah GN, Grubb JH, Pfreundschuh M and Sly WS: Human carbonic anhydrase xii: Cdna cloning, expression, and 
chromosomal localization of a carbonic anhydrase gene that is overexpressed in some renal cell cancers. Proc Natl Acad Sci USA 95(13): 7608-7613, 1998. PMID: 9636197. DOI: DOI $10.1073 /$ pnas. 95.13 .7608

14 Neri D and Supuran CT: Interfering with ph regulation in tumours as a therapeutic strategy. Nat Rev Drug Discov 10(10): 767-777, 2011. PMID: 21921921. DOI: 10.1038/nrd3554

15 Chia SK, Wykoff CC, Watson PH, Han C, Leek RD, Pastorek J, Gatter KC, Ratcliffe P and Harris AL: Prognostic significance of a novel hypoxia-regulated marker, carbonic anhydrase ix, in invasive breast carcinoma. J Clin Oncol 19(16): 3660-3668, 2001. PMID: 11504747. DOI: 10.1200/Jco.2001.19.16.3660

16 Zatovicova M, Jelenska L, Hulikova A, Csaderova L, Ditte Z, Ditte P, Goliasova T, Pastorek J and Pastorekova S: Carbonic anhydrase ix as an anticancer therapy target: Preclinical evaluation of internalizing monoclonal antibody directed to catalytic domain. Curr Pharm Des 16(29): 3255-3263, 2010. PMID: 20819068.

17 Supuran CT: Advances in structure-based drug discovery of carbonic anhydrase inhibitors. Expert Opin Drug Discov 12(1): 61-88, 2017. PMID: 27783541. DOI: 10.1080/17460441. 2017.1253677

18 Carta F, Vullo D, Osman SM, AlOthman Z and Supuran CT: Synthesis and carbonic anhydrase inhibition of a series of slc0111 analogs. Bioorg Med Chem 25(9): 2569-2576, 2017. PMID: 28347633. DOI: 10.1016/j.bmc.2017.03.027

19 Haddad RI, Weinstein LJ, Wieczorek TJ, Bhattacharya N, Raftopoulos H, Oster MW, Zhang X, Latham VM Jr., Costello R, Faucher J, DeRosa C, Yule M, Miller LP, Loda M, Posner MR and Shapiro GI: A phase ii clinical and pharmacodynamic study of e7070 in patients with metastatic, recurrent, or refractory squamous cell carcinoma of the head and neck: Modulation of retinoblastoma protein phosphorylation by a novel chloroindolyl sulfonamide cell cycle inhibitor. Clin Cancer Res 10(14): 4680-4687, 2004. PMID: 15269140. DOI: 10.1158/ 1078-0432.CCR-04-0229

20 Ariser W: Adjuvant rencarex immunotherapy phase iii trial to study efficacy in non metastatic rcc. Clinicaltrialsgov, 2018. PMID, DOI: NCT00087022

21 McDonald PC, Winum JY, Supuran CT and Dedhar S: Recent developments in targeting carbonic anhydrase ix for cancer therapeutics. Oncotarget 3(1): 84-97, 2012. PMID: 3292895, DOI: $10.18632 /$ oncotarget.422

22 Petrul HM, Schatz CA, Kopitz CC, Adnane L, McCabe TJ, Trail P, Ha S, Chang YS, Voznesensky A, Ranges G and Tamburini PP: Therapeutic mechanism and efficacy of the antibody-drug conjugate bay 79-4620 targeting human carbonic anhydrase 9 . Mol Cancer Ther 11(2): 340-349, 2012. PMID: 22147747. DOI: 10.1158/1535-7163.MCT-11-0523

23 Povoski SP, Hall NC, Murrey DA, Jr., Sharp DS, Hitchcock CL, Mojzisik CM, Bahnson EE, Knopp MV, Martin EW, Jr. and Bahnson RR: Multimodal imaging and detection strategy with 124 i-labeled chimeric monoclonal antibody $\mathrm{cg} 250$ for accurate localization and confirmation of extent of disease during laparoscopic and open surgical resection of clear cell renal cell carcinoma. Surg Innov 20(1): 59-69, 2013. PMID: 3758170. DOI: $10.1177 / 1553350612438416$

24 Knowles SM and Wu AM: Advances in immuno-positron emission tomography: Antibodies for molecular imaging in oncology. J Clin Oncol 30(31): 3884-3892, 2012. PMID: 3478579, DOI: $10.1200 / J C O .2012 .42 .4887$
25 Murri-Plesko MT, Hulikova A, Oosterwijk E, Scott AM, Zortea A, Harris AL, Ritter G, Old L, Bauer S, Swietach P and Renner C: Antibody inhibiting enzymatic activity of tumour-associated carbonic anhydrase isoform ix. Eur J Pharmacol 657(1-3): 173183, 2011. PMID: 21315712. DOI: 10.1016/j.ejphar.2011.01.063

26 von Neubeck B, Gondi G, Riganti C, Pan C, Parra Damas A, Scherb H, Erturk A and Zeidler R: An inhibitory antibody targeting carbonic anhydrase xii abrogates chemoresistance and significantly reduces lung metastases in an orthotopic breast cancer model in vivo. Int J Cancer 143(8): 2065-2075, 2018. PMID: 29786141. DOI: 10.1002/ijc.31607

27 Kobayashi M, Matsumoto T, Ryuge S, Yanagita K, Nagashio R, Kawakami Y, Goshima N, Jiang SX, Saegusa M, Iyoda A, Satoh Y, Masuda N and Sato Y: Caxii is a sero-diagnostic marker for lung cancer. PLoS One 7(3), 2012. PMID 22439015. DOI: 10.1371/journal.pone.0033952

28 Gondi G, Mysliwietz J, Hulikova A, Jen JP, Swietach P, Kremmer E and Zeidler R: Antitumor efficacy of a monoclonal antibody that inhibits the activity of cancer-associated carbonic anhydrase xii. Cancer Res 73(21): 6494-6503, 2013. PMID: 24030978. DOI: 10.1158/0008-5472.Can-13-1110

29 Breous-Nystrom E, Schultze K, Meier M, Flueck L, Holzer C, Boll M, Seibert V, Schuster A, Blanusa M, Schaefer V, Grawunder U, Martin-Parras L and van Dijk MA: Retrocyte display (r) technology: Generation and screening of a high diversity cellular antibody library. Methods 65(1): 57-67, 2014. PMID: 24036249. DOI: 10.1016/j.ymeth.2013.09.003

30 Kitamura T, Onishi M, Kinoshita S, Shibuya A, Miyajima A and Nolan GP: Efficient screening of retroviral cdna expression libraries. Proceedings of the Proc Natl Acad Sci USA 92(20): 9146-9150, 1995. PMID: 7568090. DOI: 10.1073/pnas. 92.20.9146

31 Uda NR, Seibert V, Stenner-Liewen F, Muller P, Herzig P, Gondi G, Zeidler R, van Dijk M, Zippelius A and Renner C: Esterase activity of carbonic anhydrases serves as surrogate for selecting antibodies blocking hydratase activity. J Enzyme Inhib Med Chem 30(6): 955-960, 2015. PMID: 25775095. DOI: 10.3109/ 14756366.2014 .1001754

32 Chiche J, Ilc K, Brahimi-Horn MC and Pouyssegur J: Membranebound carbonic anhydrases are key ph regulators controlling tumor growth and cell migration. Adv Enzyme Regul 50(1): 20-33, 2010. PMID: 19895836. DOI: 10.1016/ j.advenzreg.2009.10.005

33 Hsieh MJ, Chen KS, Chiou HL and Hsieh YS: Carbonic anhydrase xii promotes invasion and migration ability of mdamb-231 breast cancer cells through the p38 mapk signaling pathway. Eur J Cell Biol 89(8): 598-606, 2010. PMID: 20434230. DOI: 10.1016/j.ejcb.2010.03.004

34 Zheng B, Liu J, Gu JL, Lu Y, Zhang W, Li M and Lu H: A threegene panel that distinguishes benign from malignant thyroid nodules. Int $\mathrm{J}$ Cancer 136(7): 1646-1654, 2015. PMID: 25175491. DOI: $10.1002 / \mathrm{ijc} .29172$

35 Leppilampi M, Saarnio J, Karttunen TJ, Kivela J, Pastorekova S, Pastorek J, Waheed A, Sly WS and Parkkila S: Carbonic anhydrase isozymes ix and xii in gastric tumors. World J Gastroenterol 9(7): 1398-1403, 2003. PMID: 12854129. DOI: 10.3748/wjg.v9.i7.1398

36 Kivela A, Parkkila S, Saarnio J, Karttunen TJ, Kivela J, Parkkila AK, Waheed A, Sly WS, Grubb JH, Shah G, Tureci O and Rajaniemi H: Expression of a novel transmembrane carbonic anhydrase isozyme xii in normal human gut and colorectal tumors. Am J Pathol 156(2): 577-584, 2000. PMID: 10666387. DOI: $10.1016 / \mathrm{S} 0002-9440(10) 64762-1$ 
37 Wykoff CC, Beasley N, Watson PH, Campo L, Chia SK, English R, Pastorek J, Sly WS, Ratcliffe P and Harris AL: Expression of the hypoxia-inducible and tumor-associated carbonic anhydrases in ductal carcinoma in situ of the breast. Am J Pathol 158(3): 1011-1019, 2001. PMID: 11238049. DOI: 10.1016/S00029440(10)64048-5

38 Haapasalo J, Hilvo M, Nordfors K, Haapasalo H, Parkkila S, Hyrskyluoto A, Rantala I, Waheed A, Sly WS, Pastorekova S, Pastorek $\mathrm{J}$ and Parkkila AK: Identification of an alternatively spliced isoform of carbonic anhydrase xii in diffusely infiltrating astrocytic gliomas. Neuro Oncol 10(2): 131-138, 2008. PMID: 18322268. DOI: $10.1215 / 15228517-2007-065$

39 Chien MH, Ying TH, Hsieh YH, Lin CH, Shih CH, Wei LH and Yang SF: Tumor-associated carbonic anhydrase xii is linked to the growth of primary oral squamous cell carcinoma and its poor prognosis. Oral Oncol 48(5): 417-423, 2012. PMID: 22172588. DOI: $10.1016 /$ j.oraloncology.2011.11.015

40 Ochi F, Shiozaki A, Ichikawa D, Fujiwara H, Nakashima S, Takemoto K, Kosuga T, Konishi H, Komatsu S, Okamoto K, Kishimoto M, Marunaka Y and Otsuji E: Carbonic anhydrase xii as an independent prognostic factor in advanced esophageal squamous cell carcinoma. J Cancer 6(10): 922-929, 2015. PMID: 26316888. DOI: 10.7150/jca.11269

41 Dubois LJ, Niemans R, van Kuijk SJ, Panth KM, Parvathaneni NK, Peeters SG, Zegers CM, Rekers NH, van Gisbergen MW, Biemans R, Lieuwes NG, Spiegelberg L, Yaromina A, Winum JY, Vooijs M and Lambin P: New ways to image and target tumour hypoxia and its molecular responses. Radiother Oncol 116(3): 352-357, 2015. PMID: 26324018. DOI: 10.1016/ j.radonc.2015.08.022
42 Yoo Ri Moon GYJ: Antibody binding to carbonic anhydrase and use thereof. US Patent App 15/344, 2017.

43 Doyen J, Parks SK, Marcie S, Pouyssegur J and Chiche J: Knock-down of hypoxia-induced carbonic anhydrases ix and xii radiosensitizes tumor cells by increasing intracellular acidosis. Front Oncol 2: 199, 2012. PMID: 3539669. DOI: 10.3389/ fonc 2012.00199

44 Lounnas N, Rosilio C, Nebout M, Mary D, Griessinger E, Neffati Z, Chiche J, Spits H, Hagenbeek TJ, Asnafi V, Poulsen SA, Supuran CT, Peyron JF and Imbert V: Pharmacological inhibition of carbonic anhydrase xii interferes with cell proliferation and induces cell apoptosis in t-cell lymphomas. Cancer Lett 333(1): 76-88, 2013. PMID: 23348702. DOI: 10.1016/j.canlet.2013.01.020

45 Kopecka J, Campia I, Jacobs A, Frei AP, Ghigo D, Wollscheid B and Riganti C: Carbonic anhydrase xii is a new therapeutic target to overcome chemoresistance in cancer cells. Oncotarget 6(9): 6776-6793, 2015. PMID: 4466649. DOI: 10.18632/ oncotarget.2882

46 Kopecka J, Rankin GM, Salaroglio IC, Poulsen SA and Riganti $\mathrm{C}$ : P-glycoprotein-mediated chemoresistance is reversed by carbonic anhydrase xii inhibitors. Oncotarget 7(52): 8586185875, 2016. PMID: 5349880. DOI: 10.18632/oncotarget.13040

Received June 12, 2019

Revised July 2, 2019

Accepted July 3, 2019 